\title{
DIRECT-DRIVE CONTACTLESS WIND GENERATOR WITH CONCENTRATED WINDING
}

\author{
N. Levin, V. Pugachov, S. Orlova \\ Institute of Physical Energetics, \\ 21 Aizkraukles Str., Riga, LV-1006, LATVIA
}

\begin{abstract}
A clear trend has emerged in the field of wind power industry concerning the creation of low-, medium-, and even high-power direct-drive wind turbines without the use of gearboxes. Such generators are usually multipolar and mostly excited from permanent magnets. In the low-speed performance, multipolarity means a higher specific torque and reliability as well as lower operating costs, which in the case of high-speed generators is hindered by gearboxes. Multipolarity with a high specific torque can be achieved mainly through the use of permanent magnets of high-energy materials (such as $\mathrm{NdFeB}$ ) and through design solutions for the armature winding. The authors compare two most common types of wind generator's armature windings: the distributed one, which contains a coil embracing several teeth, and the concentrated armature winding - with one coil for one stator tooth. The comparison (along with the experience in developing the wind turbines) shows that the concentrated winding version has a number of advantages, the main of them being the multipolarity. This means that the generator with a concentrated winding can be more acceptable for the direct-drive wind turbines, is easier to make and simpler to operate. Another very important advantage of concentrated windings shown in this work is that they allow achievement of a higher specific electromagnetic torque, which means smaller size and weight of such a generator in the low-speed version.
\end{abstract}

Key words: concentrated winding, distributed winding, permanent magnet synchronous generator, stator slot skewing.

\section{INTRODUCTION}

In recent years, the interest has increased as to the use in the wind power of permanent magnet synchronous generators. This is due to three main advantages of such electric machines.

The first advantage is that they can perform as multipolar and be employed at low rotational speed without gearboxes in a wind power plant (WPP).

The second advantage is higher efficiency of the generator, increased reliability and better maintainability. The first multipolar generators were of the inductor-type and based on the electromagnetic excitation, which means high energy consumption [1-4]. Such excitation can lead to failures of the electric machine functioning due to reduced reliability; generators with electromagnetic excitation, besides the worse use of installed power, are more costly in operation.

The third advantage of permanent magnet generators is a significant increase in the specific electromagnetic torque, which means decrease in the weight-size per unit of developed power - a very important parameter for the low-speed wind turbine. 
In turn, the weight-size parameters of such generators to a large extent depend on the type of armature winding and the magnetic system, so these issues call for a deeper consideration.

\section{THE DISTRIBUTED AND THE CONCENTRATED ARMATURE WINDING IN A PERMANENT MAGNET GENERATOR}

As the criterion for comparison of generators with different type armature windings we used the electromagnetic torque instead of the developed power (when it is necessary to consider the rotational speed and other parameters affecting the efficiency of compared designs).

Figure 1 presents a fragment of the tooth zone of a three-phase generator with six teeth on the stator and a double pole pitch of the rotor. This number of stator teeth was defined from the known relation for AC machines with distributed windings:

$$
Z_{1}=2 p m q,
$$

where $m=3$ is the number of phases;

$p=1$ is the number of pole pairs;

$q=1$ is the number of slots per pole and phase.

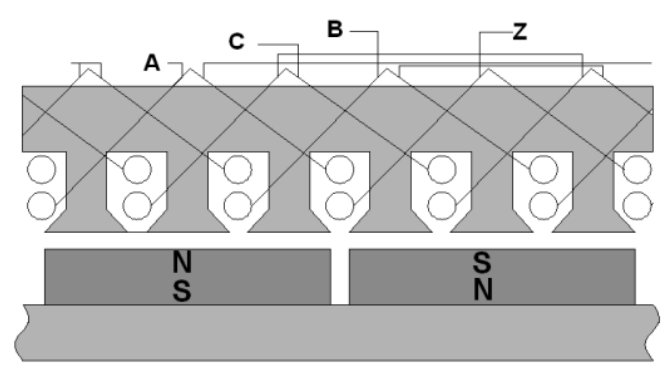

Fig. 1. A fragment of the tooth zone of a wind generator with distributed winding $\left(Z_{1}=6,2 p=2\right)$.

The electromagnetic torque can be found from the expression:

$$
\begin{aligned}
M & =-p \cdot w_{k} \cdot \frac{\partial}{\partial \alpha} \cdot\left[i_{A} \cdot \Phi_{m} \cdot \cos (p \alpha)-i_{C} \cdot \Phi_{m} \cdot \cos (p \alpha-60)+\right. \\
& \left.+i_{B} \cdot \Phi_{m} \cdot \cos (p \alpha-120)\right]= \\
& =p^{2} \cdot \Phi_{m} \cdot w_{k} \cdot\left[i_{A} \sin (p \alpha)-i_{C} \sin (p \alpha-60)+i_{B} \sin (p \alpha-120)\right]= \\
& =3 p^{2} \cdot \Phi_{z} \cdot w_{k} \cdot\left[i_{A} \sin (p \alpha)-i_{C} \sin (p \alpha-60)+i_{B} \sin (p \alpha-120)\right],
\end{aligned}
$$

where $\alpha \quad$ is the rotation angle of rotor;

$\Phi_{m}=3 \Phi_{z}$ is the maximum magnetic flux of the pole, with $\Phi_{z}$ being the flux of a stator tooth opposite to the magnet;

$i_{A}, i_{B}, i_{C} \quad$ are the currents of $A, B, C$ phases;

$w_{k} \quad$ is the number of turns in the coil. 
For the concentrated armature winding, by the data given the relationship between $Z_{1}$ and $p$ is:

$$
p=\frac{Z_{1}}{2} \pm k,
$$

where $k$ is an integer close to unity.

At $Z_{1}=12$ and $k=1$, the number of pole pairs is $p=3.5$. With the same number of teeth on the stator $\left(Z_{1}=6\right.$ in Fig. 1$)$ the tooth zone fragment will appear as shown in Fig. 2.

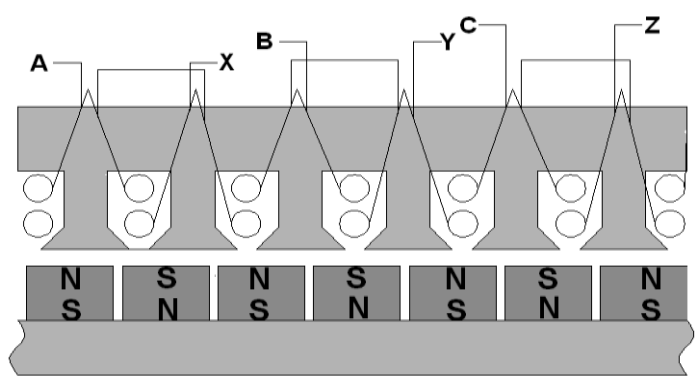

Fig.2. A fragment of the tooth zone with concentrated winding $\left(Z_{1}=12 / 2=6,2 p=7\right)$.

By analogy, the electromagnetic torque for the generator with a concentrated winding will be:

$$
\begin{aligned}
M & =-\frac{p w_{k}}{3.5} \cdot \frac{\partial}{\partial \alpha} \cdot\left[i_{A} \cdot \Phi_{z} \cdot \cos (p \alpha)+i_{B} \cdot \Phi_{z} \cdot \cos (p \alpha-120)+\right. \\
& \left.+i_{C} \cdot \Phi_{Z} \cdot \cos (p \alpha-240)\right]= \\
& =\frac{p^{2}}{3.5} \cdot \Phi_{z} \cdot w_{k} \cdot\left[i_{A} \sin (p \alpha)+i_{B} \sin (p \alpha-120)+i_{C} \sin (p \alpha-240)\right] .
\end{aligned}
$$

Comparison of (2) and (4) shows that at similar geometry of the tooth zone and the stator winding data - i.e. the areas of stator slots and the number of turns are equal while the number of pole pairs in both designs is in the 1:3.5 proportion the electromagnetic torque in the generator with a concentrated winding is $17 \%$ higher.

Thus, it is possible to create a multipolar generator in which the use of concentrated winding can allow for increasing the specific electromagnetic torque.

As concerns further mass reduction, this can be expected due to reducing $\sim 3.5$ times the height of the stator and rotor yokes. This is achievable through a significantly reduced permanent magnet flux in the generators with concentrated windings.

Thus, the generator with a concentrated winding has such significant advantages as almost three-fold increase in the number of pole pairs and a marked reduction in the size and weight per unit of the torque developed. Further improvement is achieved at the annular design of generator when the diameter of stator bore is much greater than the axial length of the stator and rotor core. Equally important is the significantly shorter length of the armature winding frontal 
parts. They are shortened several times compared with a distributed winding, which means reduced consumption of copper, smaller weight of the generator and increased stability of its external characteristics.

However, the magnetoelectric generator with a concentrated winding has a significant disadvantage - the increased starting torque due to the toothed stator and rotor and the hysteresis losses.

\section{STARTING TORQUE AND THE DESIGN STEPS TO ITS REDUCTION}

As noted, the permanent magnet generator with a concentrated winding has a high starting torque. This means a higher minimum of the wind speed at which the wind generator starts to produce power. The starting torque is associated with two factors: the hysteresis loss and the toothed stator and rotor. Losses of the type occur in generators with distributed windings, and, even more notable, because of the increased weight of the stator and rotor yokes $[5,6]$. However, the torque due to toothed execution of stator and rotor appears more in the generators with concentrated windings. Figure 3 shows the overlap of stator teeth with magnets on the rotor.

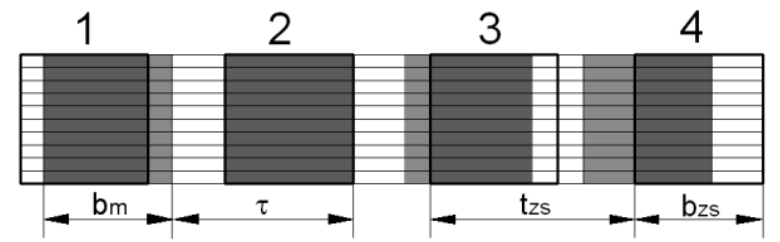

Fig.3. Changes in the area of overlap of the stator teeth and the rotor magnets;

$b_{m}$-magnet width (marked with color) and $b_{z s}$ - width of stator teeth (marked with a frame).

The magnet width $b_{m}$ is chosen equal to the width of stator tooth $b_{z s}$. In this case, due to differences in stator tooth pitch $t_{z s}$ and pole pitch $\tau$, the rotor magnets will be in a different position relative to the stator teeth. So, for example, at the rotor turning left, its pole is running up on the first tooth of stator not fully covering it. At the time, the second stator tooth is completely covered with the magnet. The magnet begins to move from the third tooth becoming half gone from the fourth one. Thus, the overlap of the teeth with the magnets at this moment is different. Since the energy at no-load is mainly concentrated in the air gap defined by the overlap areas while the rotor turning is connected with variations in these areas, the derivative of the energy stored with respect to the rotation angle determines the moment of resistance or "jerk" forward.

Based on the foregoing, the first constructive step to reduce the cogging torque is to ensure the constancy of the area of the stator teeth overlapping with the rotor magnet, regardless of its position. This requires that the magnet width $b_{m}$ is equal to stator tooth pitch $t_{z s}$, i.e.

$$
b_{m}=t_{z s},
$$

as shown in Fig. 4.

As follows from this figure, the magnets of rotor always cover one or two stator teeth with a constant total area. 


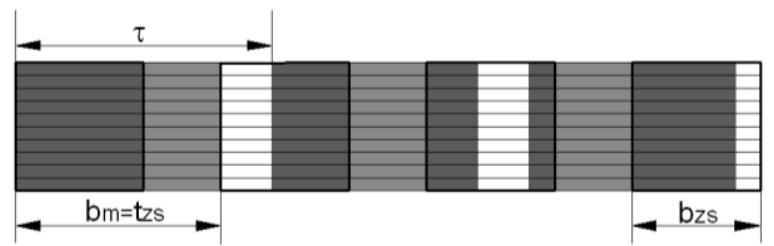

Fig. 4. The overlap areas of the teeth and magnets $\left(b_{m}=t_{z s}\right)$.

Figure 5 shows the overlap of stator teeth and rotor magnets, with $b_{m}=t_{z s}$ and the skewing of stator slot at its opening being

$$
b_{s}=b_{w},
$$

i.e. equal to the rotor interpolar distance $b_{w}$.

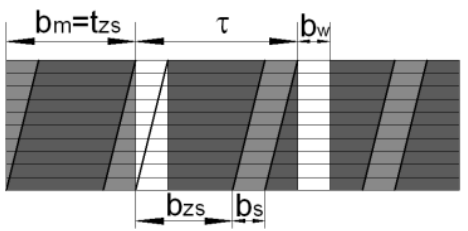

Fig. 5. The overlap areas of stator teeth and rotor magnets in the case of stator slot skewing.

As follows from Fig. 5, when the stator slot is skewed, for its opening not only the constancy of the overlap areas is observed, but also smooth entry into and exit from the stator tooth - the magnet rotor interaction zone. The torque fluctuation curves of running rotor are shown in Fig. 6 for the cases with and without stator slot skewing.

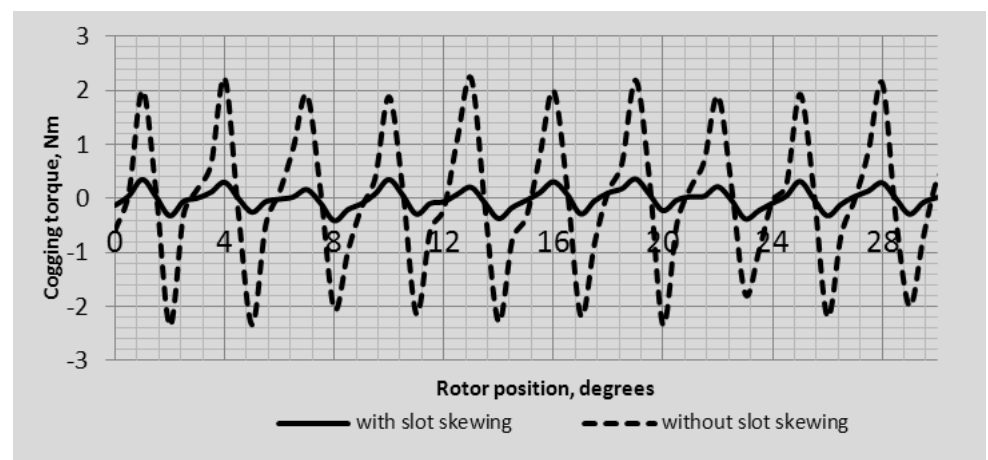

Fig. 6. Variations in the cogging torque at running rotor, with and without stator slot skewing.

\section{RESULTS OF EXPERIMENTAL STUDIES \\ OF PERMANENT MAGNET SYNCHRONOUS GENERATORS}

The experimental studies were carried out for two generators:

1. Generator GL-PMG-5000. The manufacturer: GINLONG co. This company produces wind turbines in the power range from 500 to $5000 \mathrm{~W}$.

2. Generator FEI-SGPM-1400, designed at the Institute of Physical Energetics and produced by Dotan Maritime Industries Ltd.

The basic parameters of the generators are tabulated below. 
Parameters of generators

\begin{tabular}{|c|l|c|c|}
\hline Nr. & \multicolumn{1}{|c|}{ Title } & GL-PMG-5000 & SGPM-1400 \\
\hline 1 & Nominal power, $\mathrm{W}$ & 5000 & 1400 \\
\hline 2 & ${\text { Rotational speed, } \text { min }^{-1}}$ & 200 & 250 \\
\hline 3 & Voltage, $\mathrm{V}$ & 650 & 175 \\
\hline 4 & Rectified current, $\mathrm{A}$ & 10 & 8 \\
\hline 5 & Input torque, $\mathrm{Nm}$ & 269 & 70 \\
\hline 6 & Phase resistance, $\Omega$ & 3.3 & 1.4 \\
\hline 7 & Winding type & distributed & concentrated \\
\hline 8 & Number of pole pair & 8 & 10 \\
\hline 9 & Starting torque, $\mathrm{Nm}$ & $\leq 3.5$ & $\leq 1.6$ \\
\hline 10 & Generator weight, $\mathrm{kg}$ & 140 & 27 \\
\hline 11 & Efficiency & 0.79 & 0.8 \\
\hline 12 & Specific torque, $\mathrm{Nm} / \mathrm{kg}$ & 1.92 & 2.2 \\
\hline
\end{tabular}

The general view of the FEI-SGPM-1400 generator is shown in Fig. 7.

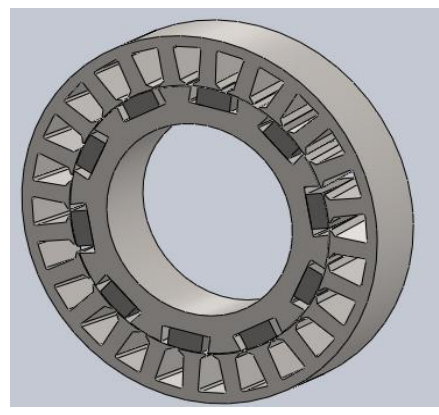

Fig.7. Permanent magnet synchronous generator: the design of the Institute of Physical Energetics.

As follows from the data presented in Table 1, the concentrated armature winding in permanent magnet generators significantly improves their technical and economic indices. A generator of the type with a concentrated winding, despite its smaller output power, has a higher specific torque and efficiency, better manufacturability (simpler coils, placing the armature winding in open slots, high maintainability, etc.).

\section{CONCLUSION}

As shown by the results of studies, the direct-drive magnetoelectric generators with concentrated windings have a number of significant advantages over those with distributed ones. They have a higher specific torque and efficiency, are reliable in operation and easy to maintain, being at the same time significantly cheaper to make due to less consumption of electrical steel, copper and magnetic materials. 


\title{
ACKNOWLEDGMENT
}

This article has been supported by the National Research Programme „Technologies for Innovative Production and Use of Energy Resources and Provision of Low Carbon Emissions by Means of Renewable Energy Sources, Support Measures for the Mitigation of Environment and Climate Degradation LATENERGI"

\section{REFERENCES}

1. Kopilov, I., \& Ljadova, T. (1988). Wind turbine without gearbox. Hydro project, Nr.129, 170-174 (in Russian).

2. Levin, N., \& Serebrjakov, A. (1991). Inductor generator in small power wind turbine. Energy buildings, (3), 53-55 (in Russian).

3. Dirba, J., Levin, N., \& Pugachov, V. (2006). Vēja Energíjas elektromehāniskie pārveidotāji. Rīga: RTU, p. 312 (in Latvian).

4. Spooner, E., \& Williamson, A. (1996). Direct coupled permanent magnet generators for wind turbine applications. IEEE proceedings, Electric Power Appl., 143 (1).

5. Postnikov, I. (1975). Total theory and transiet processes in electrical machines. Moscow: High School, 220 (in Russian).

6. Kopilov, I. (1987). Mathematical modelling of electrical machine. Moscow: High School, 248 (in Russian).

\section{TIEŠAS PIEDZIN̦AS BEZKONTAKTU ĢENERATORS AR KONCENTRĒTO TINUMU}

\author{
N. Levins, V. Pugačevs, S. Orlova
}

Kopsavilkums

Vēja enerǵêtikas nozarē iezīmējās acīmredzama tendence mazas, vidējas un pat lieljaudas tiešas piedzinas vēja ğeneratoru izveidošanā bez multiplikatoriem. Tādi generatori parasti tiek izveidoti kā daudzpolu un lielākoties ar ierosmi no pastāvīgiem magnētiem

Lēngaitas ǵeneratoriem daudzpolainība paaugstina īpatnējo momentu, drošumu un samazina ekspluatācijas izdevumus. Galvenie šķēršlii, lai sasniegtu minētās priekšrocības ātrgaitas ǵeneratoros, ir multiplikatori.

Daudzpolainība un liels īpatnējais moments var tikt sasniegti ar pastāvīgo magnētu pielietošanu, kas izgatavoti no augsti enerǵētiski magnētiski cietiem materiāliem ( $\mathrm{NdFeB}$ tipa) un izmantojot atbilstošus konstruktīvos risinājumus enkura tinumu izgatavošanā.

Šajā darbā autori salīdzina divus visplašāk izplatîtos vēja generatoru enkura tinumus: sadalīto, kas satur spoli, kas aptver uzreiz vairākus enkura zobus, un koncentrēto - kur spole aptver vienu zobu uz statora. Vēja generatoru izstrādē uzkrātā pieredze parāda, ka koncentrētā tinumu pielietošanai ir virkne priekšrocību, no kuriem galvenā ir daudzpolainība, t.i., magnetoelektriskais generators ar zobveida tinumiem ir vispiemērotākais tiešas piedziņas VEI un turklāt ir izgatavojams, pielietojot augstas tehnologijas, un visvienkāršāk pielietojams ekspluatācijāa Turklāt, darbā tiek atklātas un pamatotas citas zobainu tinumu priekšrocības, kas ļauj iegūt augstu īpatnējo elektromagnētisko momentu, t.i., lēngaitas izpildījumā ir mazāki gabarīti un masa.

20.07.2012. 